\title{
EMG1 is essential for mouse pre-implantation embryo development
}

Xiaoli Wu', Sumit Sandhu', Nehal Patel ${ }^{1}$, Barbara Triggs-Raine ${ }^{1,2,3}$, Hao Ding ${ }^{1,3^{*}}$

\begin{abstract}
Background: Essential for mitotic growth 1 (EMG1) is a highly conserved nucleolar protein identified in yeast to have a critical function in ribosome biogenesis. A mutation in the human EMG1 homolog causes Bowen-Conradi syndrome (BCS), a developmental disorder characterized by severe growth failure and psychomotor retardation leading to death in early childhood. To begin to understand the role of EMG1 in mammalian development, and how its deficiency could lead to Bowen-Conradi syndrome, we have used mouse as a model. The expression of Emg1 during mouse development was examined and mice carrying a null mutation for Emg1 were generated and characterized.

Results: Our studies indicated that Emg1 is broadly expressed during early mouse embryonic development. However, in late embryonic stages and during postnatal development, Emg1 exhibited specific expression patterns. To assess a developmental role for EMG1 in vivo, we exploited a mouse gene-targeting approach. Loss of EMG1 function in mice arrested embryonic development prior to the blastocyst stage. The arrested Emg 1/- embryos exhibited defects in early cell lineage-specification as well as in nucleologenesis. Further, loss of p53, which has been shown to rescue some phenotypes resulting from defects in ribosome biogenesis, failed to rescue the Emg 1 ${ }^{-1-}$ pre-implantation lethality.

Conclusion: Our data demonstrate that Emg1 is highly expressed during mouse embryonic development, and essential for mouse pre-implantation development. The absolute requirement for EMG1 in early embryonic development is consistent with its essential role in yeast. Further, our findings also lend support to the previous study that showed Bowen-Conradi syndrome results from a partial EMG1 deficiency. A complete deficiency would not be expected to be compatible with a live birth.
\end{abstract}

\section{Background}

Ribosome biogenesis is fundamental to cell growth and accounts for a substantial proportion of a cell's energy expenditure [1]. The ribosomal RNAs (rRNAs) are central to the ribosome structure and function [2]. The rRNA genes exist as tandem repeats and form the foci upon which the nucleoli form. The rRNA precursor (47S) is synthesized from the genes by RNA polymerase I and assembled with ribosomal proteins to form the $90 \mathrm{~S}$ pre-ribosome. This $90 \mathrm{~S}$ preribosome is matured to form the large-60S ribosomal subunit and the small-40S ribosomal subunit. The $60 \mathrm{~S}$ subunit contains the $28 \mathrm{~S}$, $5.8 \mathrm{~S}$ and $5 \mathrm{~S}$ rRNAs as well as approximately 49 proteins,

\footnotetext{
* Correspondence: dingh@cc.umanitoba.ca

'Department of Biochemistry and Medical Genetics, University of Manitoba,

745 Bannatyne Avenue, Winnipeg R3E 0J9, Canada

Full list of author information is available at the end of the article
}

whereas the $40 \mathrm{~S}$ subunit contains the $18 \mathrm{~S}$ rRNA and approximately 33 proteins. It is estimated that 200 proteins are involved in assembling the mature ribosomes [3]. Many of them have been studied in yeast, but not in mammals. Nonetheless, the proteins are highly conserved and as a starting point, it is reasonable to assume that they function similarly in mammals.

EMG1 (also known as Nep1) was initially identified as "Essential for Mitotic Growth" in yeast [4], and later was shown to be involved in the biogenesis of the mature $40 \mathrm{~S}$ ribosome [5,6]. Yeast EMG1 (yEMG1) is a $28 \mathrm{kDa}$ protein primarily detected in the nucleolus $[5,6]$. Because the deletion of yEMG1 in yeast is lethal, temperature sensitive mutations in this gene have been used to study the effects of its deficiency. Depletion of yEMG1 resulted in a reduction in $18 \mathrm{~S}$ rRNA, a decrease in $40 \mathrm{~S}$ ribosomal subunits and an increase in the ratio 
of $60 \mathrm{~S}$ to $40 \mathrm{~S}$ ribosomal subunits $[5,6]$. These findings indicate an important role for EMG1 in the biogenesis of the $40 \mathrm{~S}$ ribosome.

Deciphering the precise role of EMG1 in 40S ribosome biogenesis has been challenging. A temperature sensitive mutation in yEMG1 could be suppressed by the methyl donor S-adenosyl methionine (SAM) [6] or deletion of the snR57 gene encoding a snoRNA needed for 2'-O-ribose-methylation of G1570 in the 18S rRNA [7]. Furthermore, yEMG1 was found to interact directly with snoRNA [8] and the 18S rRNA [9]. Taken together, these findings suggested that yEMG1 functions to methylate the $18 \mathrm{~S}$ rRNA, a concept that was later supported by the identification of yEMG1 as a SAM-dependent pseudouridine-N1-specific methyltransferase [10].

The EMG1 protein is highly conserved from archaebacteria to humans or mice [11]. Expression of the human orthologue of EMG1 in yeast demonstrates that it is capable of suppressing the lethal defect in $y E M G 1$ cells, indicating that EMG1 is both structurally and functionally conserved among these eukaryotes [6]. More recently, a mutation in human EMG1, which significantly reduces EMG1 protein levels, has been found to cause Bowen-Conradi syndrome (BCS), an autosomal recessive disorder characterized by severely impaired prenatal and postnatal growth, profound psychomotor retardation, and death in early childhood [12]. This finding strongly suggests that EMG1, as a key molecule in ribosomal synthesis, could be important for development. To get a better understanding of this, in the present study, we have attempted to generate an EMG1deficient mouse and characterize the expression of Emg1 during mouse development. Our data demonstrates that EMG1 is essential for mouse pre-implantation development.

\section{Results and Discussion}

\section{Expression of Emg1 during mouse embryogenesis}

As a first step toward elucidating the role of EMG1 during development, we analyzed the expression of the Emg1 gene in mouse embryos and postnatal tissues. Using RNA in situ hybridization, Emg1 expression was readily detected in E2.5 morula embryos (Figure 1A), with the strongest expression associated with the inside cells in the late stage of morula (Figure 1B). High levels of Emg1 mRNA were also detected in the inner cell mass (ICM) of mouse blastocysts (E3.5), but not in the trophectoderm (Figure 1C). This expression pattern is consistent with Emg1 being expressed highly in the embryo proper, but weakly expressed or not detectable in the trophoblasts of mouse placenta (Figure 2).

Expression of Emg1 in mouse pre-implantation embryos was also analyzed by determining the activity of LacZ in Emg1 knockout heterozygotes in which the expression of the $L a c Z$ transgene was regulated by the endogenous Emg1 regulatory elements (see Figure 3). Crosses of wild-type males with $E m g 1^{+/-}$females revealed a positive LacZ signal in zygotes and in 2-cell embryos, which was not present in those from breeding $E m g 1^{+/-}$males with wild-type females (Figure 1D), indicating that these early mouse embryos could contain maternally transmitted EMG1. However, starting at the 8-cell morula stage, there were two distinct LacZ-staining patterns for the embryos collected from the breeding of wild-type males with $E m g 1^{+/-}$females (Figure 1E). Among these embryos, $E m g 1^{+/}$showed wide-spread LacZ staining, whereas the ones that were genotyped as $\mathrm{Emgl}^{+/+}$exhibited a weak disperse staining which could be from residual maternally transmitted LacZ proteins. This data indicates that the onset of zygotic expression of EMG1 may occur at the 8-cell morula stage. In addition, X-gal staining of E3.5 Emg1 ${ }^{+/}$blastocysts showed strong LacZ staining in the ICM, but not in the trophectoderm (Figure 1E), which is consistent with Emg1 expression detected by in situ hybridization (Figure 1C).

To determine the expression pattern of Emg1 in postimplantation embryos, mouse embryos at E8.5-E15.5 were analyzed. At E8.5-E9.5, Emg1 was widely and strongly expressed and showed no clear tissue-specific pattern (Figure 2A-B). At later stages (E11.5-E15.5), however, Emg1 was found to be expressed at a low level in most embryonic tissues, but strongly in several regions, including the ventricular zone of the neuroepithelium (Figure 2C), the neural layer of retina (Figure 2D), the follicles of vibrissae (Figure 2E), thymus (Figure 2F), submandibular glands (Figure 2G), brown adipose tissue (Figure 2H), lung (Figure 2I), nephric tubules and renal mesenchyme (Figure 2J) and seminiferous tubules in the testis (not shown).

To examine the expression of Emg1 in extraembryonic tissue, we performed RNA in situ hybridization on E8.5E9.5 mouse placenta. No Emg1 signal was detected in the trophoblast cells, while a control gene, Rtel (Regulator of Telomere length) showed strong expression in this cell lineage (Figure 2K) [13].

In adult mice, similar levels of Emg1 mRNA were detected in multiple tissues by Northern blot hybridization (Figure 2L), suggesting that EMG1 could be widely expressed during postnatal development. However, using RNA in situ hybridization assays, Emg1 cell-specific expression patterns were detected in several tissues (Figure 2M-Q). In the adult testis, Emg1 is highly and specifically expressed in both spermatogonia and early meiotic spermatocytes, but not in late stage spermatocytes (Figure 2M). A strong Emg1 signal was also identified in oocytes and the granulosa cells of the pre-antral follicles in the ovary (Figure $2 \mathrm{~N}$ ). In the adult mouse brain, Emg1 expression was mainly detected in the 
A
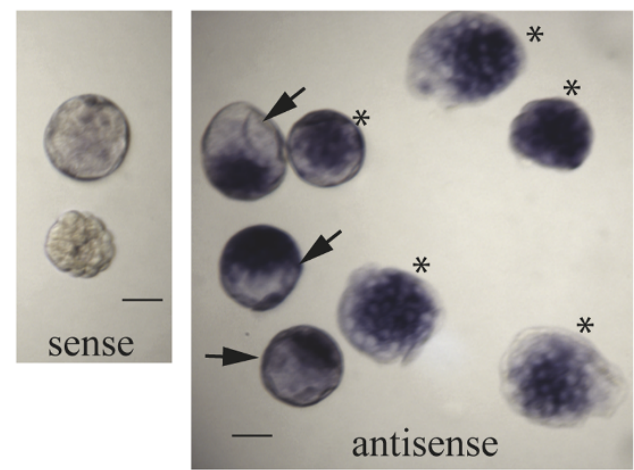

B

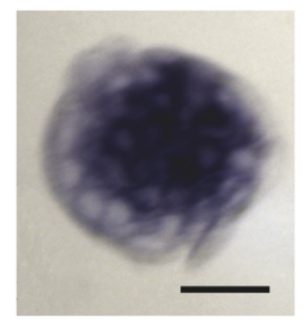

C

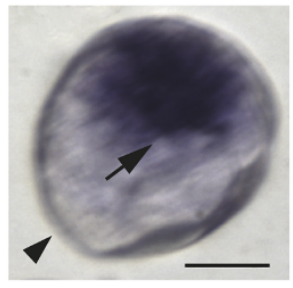

D
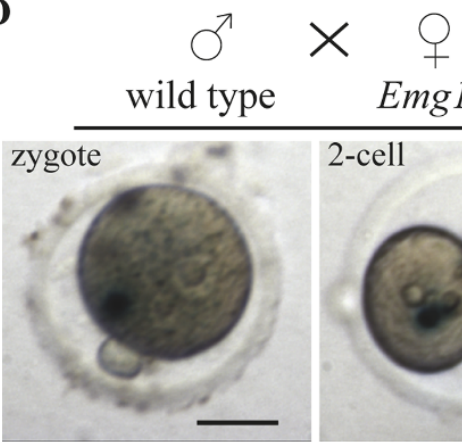

$\operatorname{Emg} 1+/-$
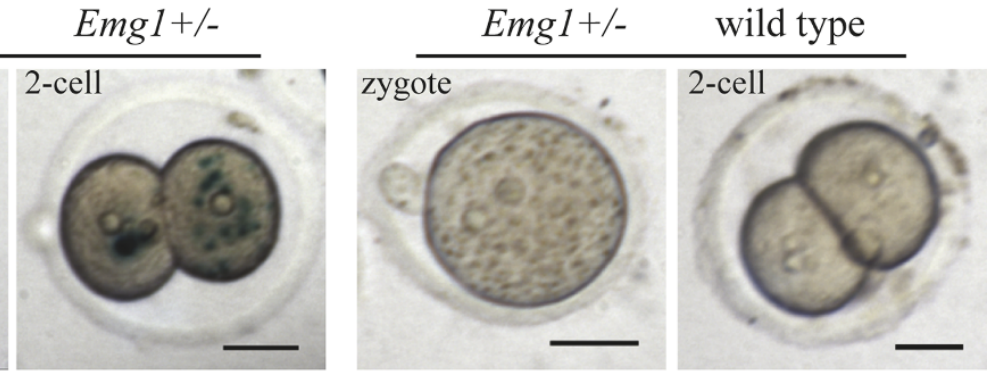

$\mathbf{E}$
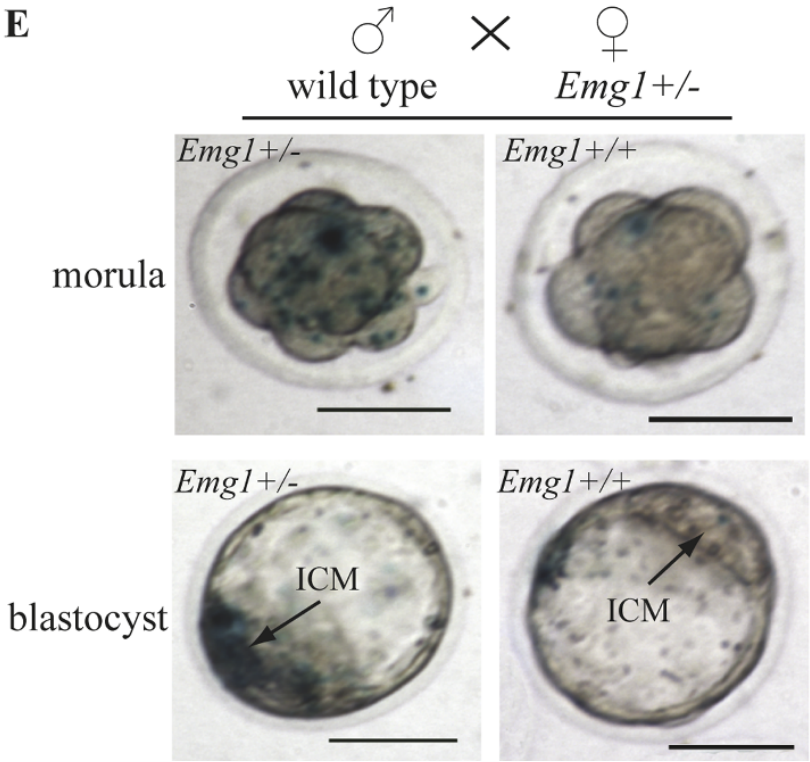

Figure 1 Expression of Emg1 in pre-implantation embryos. (A) Whole mount RNA in situ hybridization of mouse pre-implantation embryos. Asterisks indicate the E2.5 morulae, and arrows indicate the blastocysts. Hybridization with Emgl sense probe is presented as a control. (B) High magnification showing that a stronger Emgl signal is detected within the inside cells at the morula stage. (C) High magnification demonstrating that the inner cell mass of the mouse blastocyst is strongly stained with Emg1 antisense probe (arrow indicates), whereas the trophectoderm has a very low level of Emgl (arrowhead). (D) Whole mount X-gal staining of zygotes and 2-cell embryos either from the cross of wild-type males with $\mathrm{Emgl}^{+/-}$females or from Emg $1^{+/-}$males with wild-type females. Only the embryos from the breeding of wild-type males with Emg ${ }^{+/-}$ females show LacZ signals. (E) X-gal staining of morulae and blastocysts collected from the breeding of wild-type males with Emg ${ }^{1^{+>}}$females, shows wide-spread LacZ signals in the 8-cell morula and in the ICM of Emg1 ${ }^{+/}$. In Emg $1^{+/+}$morulae or blastocysts, only a few cells are weakly stained for LacZ, probably reflecting a low level of residual maternally transmitted LacZ protein in these cells. Scale bar in A-D, 50 $\mathrm{mm}$, and in

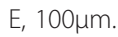




\section{A}
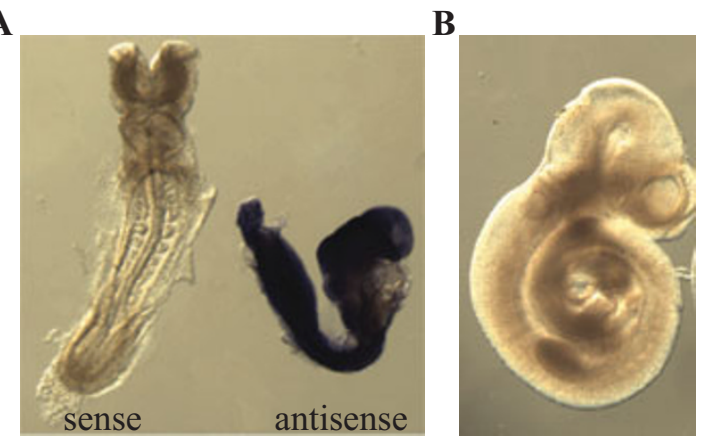

sense

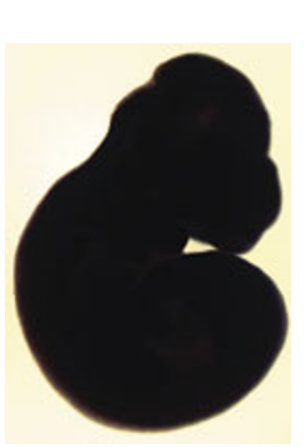

antisense
C

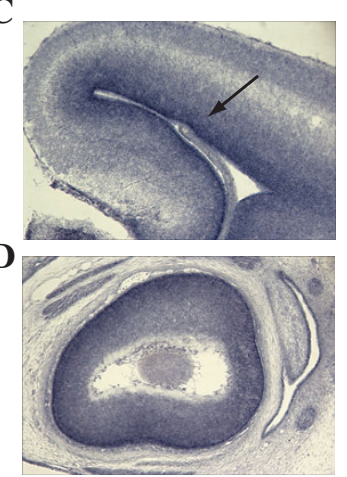

H
$\mathbf{E}$

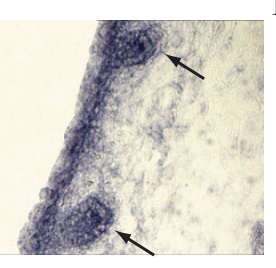

I

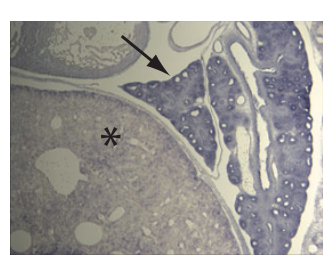

L
F

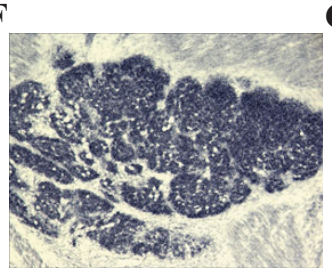

G

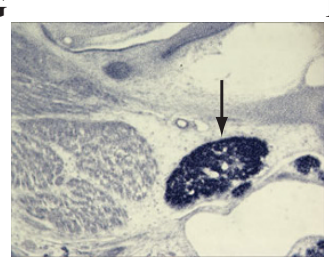

K
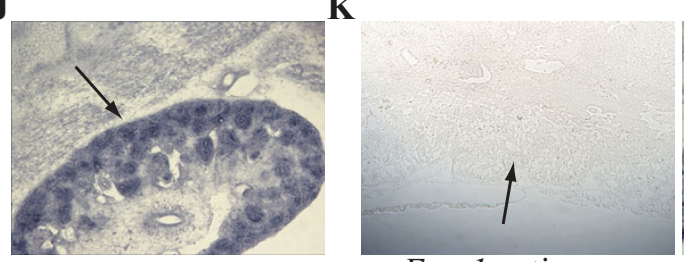

Emgl antisense

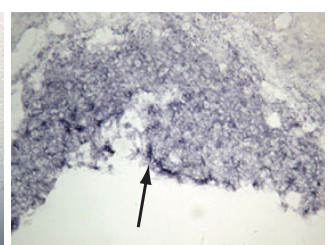

Rtel antisense

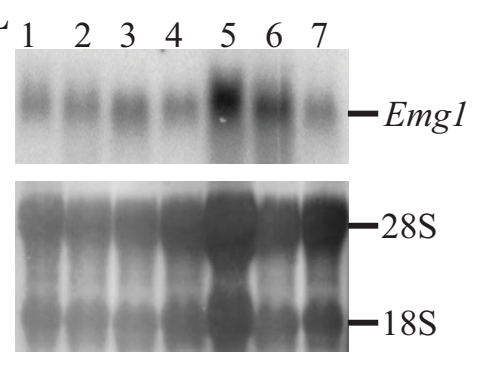

$\mathbf{O}$

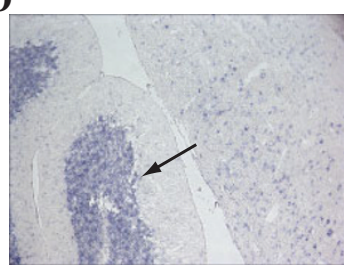

$\mathbf{P}$
M

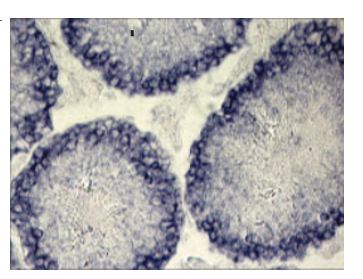

N
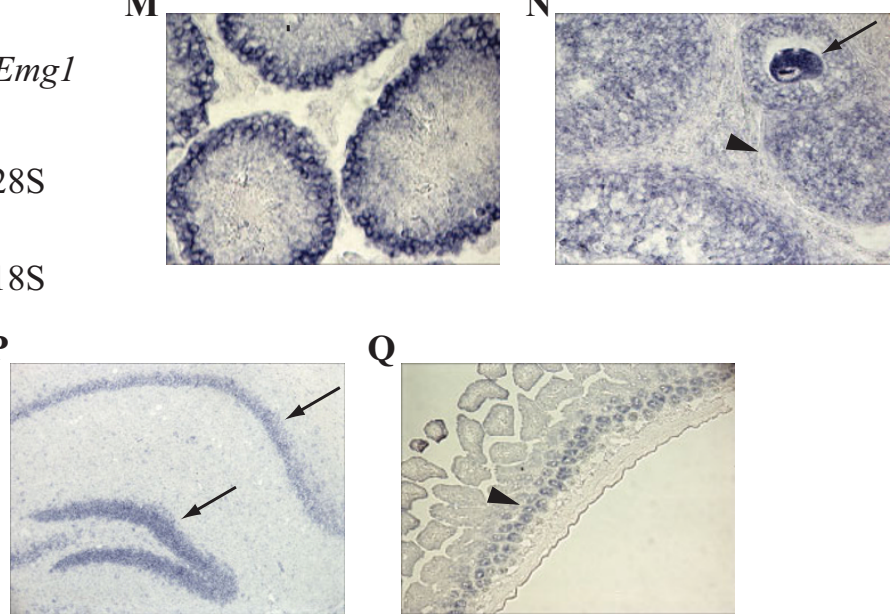

$\mathbf{Q}$

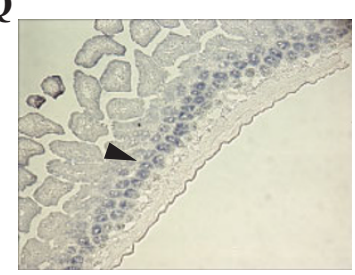

Figure 2 Expression of Emg1 in post-implantation embryos and adult mice. (A-B) Whole mount RNA in situ hybridization of postimplantation mouse embryos (A: E8.5; B: E9.5). (C-J) RNA in situ hybridization on the sections of E13.5-E15.5 mouse embryos, demonstrating that Emgl is expressed at low levels in most tissues, but strongly in the ventricular zone of the neuroepithelium ( $C$, arrow indicates), the neural layer of retina (D), the follicles of vibrissae (E, arrows indicate), thymus ( $F$ ), submandibular glands ( $G$, arrow indicates), brown adipose tissue (H, arrow indicates), lung (I, arrow indicates. Asterisk indicates liver in which low expression of Emgl was found), nephric tubules and renal mesenchyme (J, arrow indicates). (K) RNA in situ hybridization on the sections of E9.5 placenta, showing that Emg1 mRNA is low or undetectable in the trophoblast cells (arrow indicates). Rtel antisense probe is presented as a positive control. Magnification for images C-K: X10. (L) Northern blot analysis of Emg1 expression in mouse adult tissues. Lane: 1 Brain; 2 Lung; 3 Heart; 4 Liver; 5 Spleen; 6 Kidney; 7 Skeletal muscles. Lower panel shows the total ribosomal RNAs for normalization. (M) RNA in situ hybridization on mouse testis, showing that Emg1 is highly and specifically expressed in spermatogonia and meiotic spermatocytes. (N) In ovary, strong Emgl expression is detected in oocyte (arrow indicates). The granulose cells of the pre-antral follicles are also positive for $\mathrm{Emgl}$ (arrowheads). (O-P) In brain, Emgl is predominately expressed in the granular neurons of cerebellum ( $\mathrm{O}$, arrow indicates) and the neurons located in hippocampus (P, arrows indicate). (Q) In intestine, Emgl expression was mainly identified in the crypts (arrowhead). Magnification for images O-Q: x10. 
granular layer of neurons of the cerebellum (Figure 2O) as well as in the hippocampus (Figure 2P). Specific expression of Emg1 was also found in the crypts of the intestine (Figure 2Q).

Taken together, our gene expression data indicates that EMG1 is broadly distributed in the early developing embryos, but its expression is more restricted in the later stages of development. In adult mice, Emg1 also exhibits cell-specific expression, most notably in the gonads, brain and intestine. This expression pattern suggests that EMG1 may not only be important for early embryonic development, but could also be required for the development of several cell lineages at late developmental stages or during postnatal development.

\section{Generation of the Emg1 null mouse allele}

To further study the developmental role of EMG1, we have mutated Emg1 in mice by homologous recombination. The mouse Emg1 gene contains 6 exons that encode a protein composed of 244 amino acids. In order to create an Emg1 null allele, a gene-targeting vector with a splice acceptor (SA)-IRES- $\beta g e o-p A$ cassette was used to replace exons 2-6 and to remove approximately $80 \%$ of the Emg1 coding sequence (Figure 3A). Given that Emg1 is highly expressed in ES cells, the inserted $S A$-IRES $\beta$ geo cassette in the first intron of the Emg1 locus will trap exon 1 to turn on the expression of $\beta$ geo, a fusion protein of LacZ and neo. This was designed to allow us to significantly increase the targeting frequency, while also allowing us to establish a mouse allele in which a LacZ reporter is regulated by the endogenous Emg1 regulatory elements. Indeed, approximately $25 \%$ (11 out of 45 ) of the ES colonies obtained after G418 selection showed correct homologous recombination by Southern blot analysis using both 5' and 3' probes external to the targeting vector (Figure 3B-C). Furthermore, LacZ transgene expression in $E m g^{+/-}$embryos was entirely consistent with the

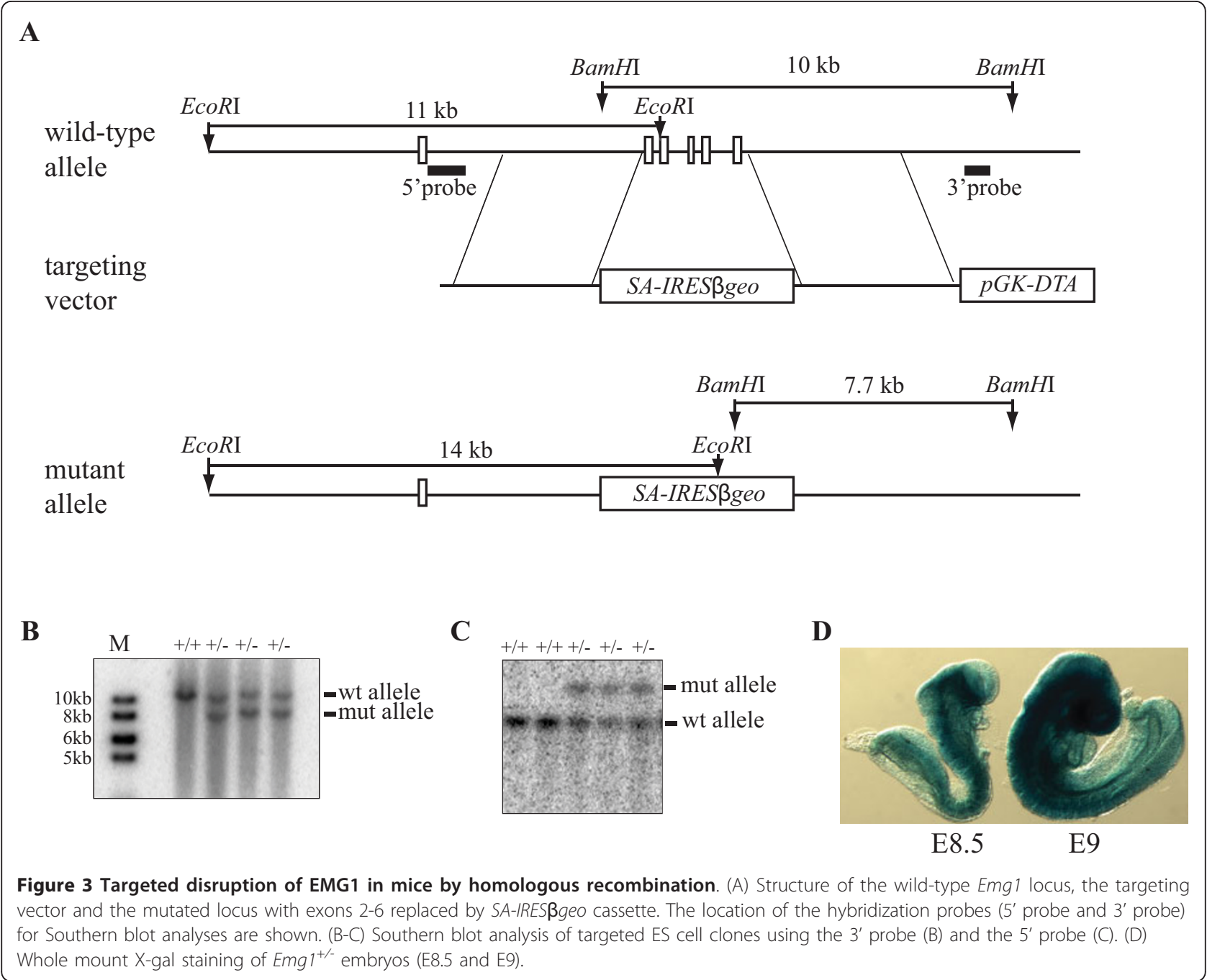


expression pattern established by in situ hybridization (Figure 1E and 3D). In this study, we have used two independently targeted ES lines to generate germlinetransmitting chimeras that were bred with $129 \mathrm{~S} 1$ or CD1 females to produce Emg1 null mutants for functional analysis.

\section{The pre-implantation lethality of Emg1 null mutants}

Both $E m g 1^{+/}$males and females were normal and fertile, and transmitted the targeted allele to about $50 \%$ of their progeny. However, no homozygous offspring were born from $\mathrm{Emgl}^{+/-}$intercrosses (Table 1, $\mathrm{n}=237$ ), indicating that loss of EMG1 function leads to embryonic lethality. To determine at which stage of development the homozygous mutant embryos died, timed heterozygous matings were performed. An analysis of embryos between E8.5-E12.5 revealed that none of the 64 embryos genotyped were $E m g 1^{-1-}$. The expected Mendelian frequency of heterozygote, homozygote and wildtype was only observed in the pre-implantation embryos (Table 1), indicating that mice lacking EMG1 protein stopped developing at the pre- and/or peri-implantation stages.

To address this further, we analyzed more than 100 pre-implantation embryos collected from two independent mouse lines carrying the Emg1 knockout allele. At E2.5, Emg1 ${ }^{+/-}$intercrosses yielded early stage embryos that were indistinguishable from each other, despite the presence of $E m g 1^{-1-}$ mutations among these progeny (Figure 4A). In addition, all the $E m g 1^{--}$embryos at this developmental stage showed similar BrdU incorporation (Figure 4B), and nearly undetectable levels of apoptosis, like that of the wild-type controls (data not shown), indicating that $E m g 1^{-1-}$ embryos were not blocked at the E2.5 stage.

The E3.5 embryos from Emg1 ${ }^{+/}$intercrosses, however, consistently showed a mixture of morula and blastocyststage embryos. Genotyping of these embryos demonstrated that whereas the blastocysts were either $E m g 1^{+/+}$ or $E m g 1^{+/-}$heterozygotes, the morula-stage embryos were $E m g 1^{-/-}$mutants (Figure 4C). In Emg $1^{-/-}$morulae,

\begin{tabular}{|c|c|c|c|c|}
\hline \multirow[t]{2}{*}{ Developmental Stage } & \multicolumn{3}{|c|}{ No. of mice by genotyping } & \multirow[t]{2}{*}{ Tota } \\
\hline & $+/+$ & $+/-$ & $-/-$ & \\
\hline Postnatal & 107 & 130 & 0 & 237 \\
\hline E12.5 & 6 & 10 & 0 & 16 \\
\hline E9.5 & 4 & 13 & 0 & 17 \\
\hline E8.5 & 11 & 20 & 0 & 31 \\
\hline E3.5 & 11 & 22 & 9 & 42 \\
\hline E2.5 & 12 & 17 & 11 & 40 \\
\hline
\end{tabular}

the blastomeres flattened and tightly aligned themselves against each other to form a compact ball of cells. Immunofluoresence (IF) with anti-E-cadherin antibody revealed that $\mathrm{Emg}^{-1-}$ morulae exhibited the same organized pattern of E-cadherin along the cell boundaries as the wild-type control (Figure 4D). These data indicate that $E m g^{--}$embryos do reach the compaction stage of morula development.

To determine whether Emg1 ${ }^{-/-}$embryos at E3.5 were arrested at this stage or simply delayed, we further cultured these embryos in vitro. After 24 h of culture, while $E m g 1^{+/+}$and $E m g 1^{+/-}$E3.5 embryos formed expanded blastocysts, none of the E3.5 Emg $1^{-1-}$ embryos developed to blastocysts (Figure 4E). Instead, many cells in the cultured mutant embryos showed fragmented, pyknotic nuclei, suggestive of cell death. To determine whether cell death is indeed increased in these cultured mutant embryos, we performed a TUNEL assay. A significantly higher number of TUNEL-positive nuclei were detected in the mutant embryos than in $\mathrm{Emgl}^{+/+}$embryos (Figure 4F). In addition, very few cells in the cultured mutant embryos were positive in the BrdU labeling assay (Figure 4G). These data clearly indicate that $E m g 1^{-/-}$embryos arrest prior to forming the blastocyst and subsequently the embryos undergo degeneration. Because of this severe phenotype, no Emg1-deficient cells could be established to perform further molecular investigations.

\section{Specification of early cell lineages in $\mathrm{Emg}^{-/}$embryos}

The failure of $E m g 1^{-1-}$ embryos to form blastocysts could suggest a defect in the specification of early cell lineages in these mutant embryos. To test this, we analyzed the expression of several early cell lineage markers, including OCT4, NANOG and CDX2, in E3.5 Emg $1^{-/}$ embryos. These markers have been shown to be widely expressed in the blastomeres of cleavage stage embryos, but become restricted to the different lineages, i.e. OCT4 and NANOG in ICM and CDX2 in trophectoderm, after initiation of blastocyst formation [14-17]. Using these lineage markers, we found that although E3.5 Emg $1^{-/-}$embryos did not form the OCT-3/4 or NANOG-positive ICM like that of $E m g 1^{+/+}$blastocysts, the blastomeres in the mutant embryos displayed levels of expression of these markers similar to wild type (Figure 5A and Additional file 1). However, the expression of CDX2 was consistently found to be significantly decreased in the mutant embryos as compared to the controls (Figure 5B). These results suggest that loss of EMG1 function more specifically down-regulates the expression of CDX2 in the blastomeres of the cleavage stage embryos, which might then influence the allocation or morphogenesis of cell lineages during early embryogenesis. 


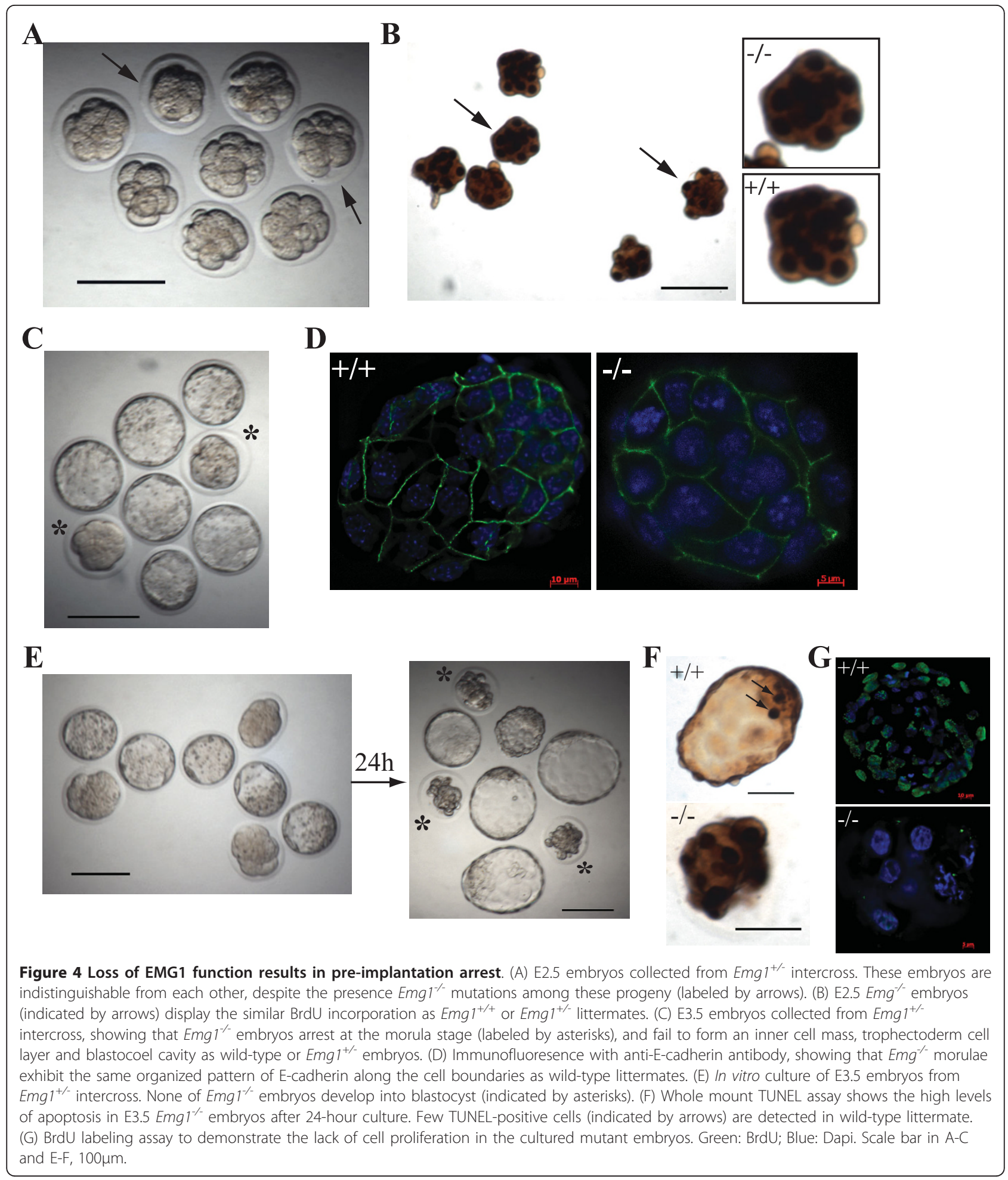

\section{Ribosomal biogenesis in $\mathrm{Emg} 1^{-/}$mutants}

EMG1 has been shown to be a highly conserved nucleolar protein required for ribosome biogenesis [5]. Emg1null mutants exhibit arrested development prior to the blastocyst stage, similar to that observed in other mouse models that lack factors involved in ribosomal RNA synthesis or processing, including RBM19 (RNA-binding motif protein 19) [18], pescadillo-1 (PES-1) [19], fibrillarin [20], RNA polymerase I or II [21], BYSL [22], SURF6 [23] and RPS19 (ribosomal protein S19) [24]. 


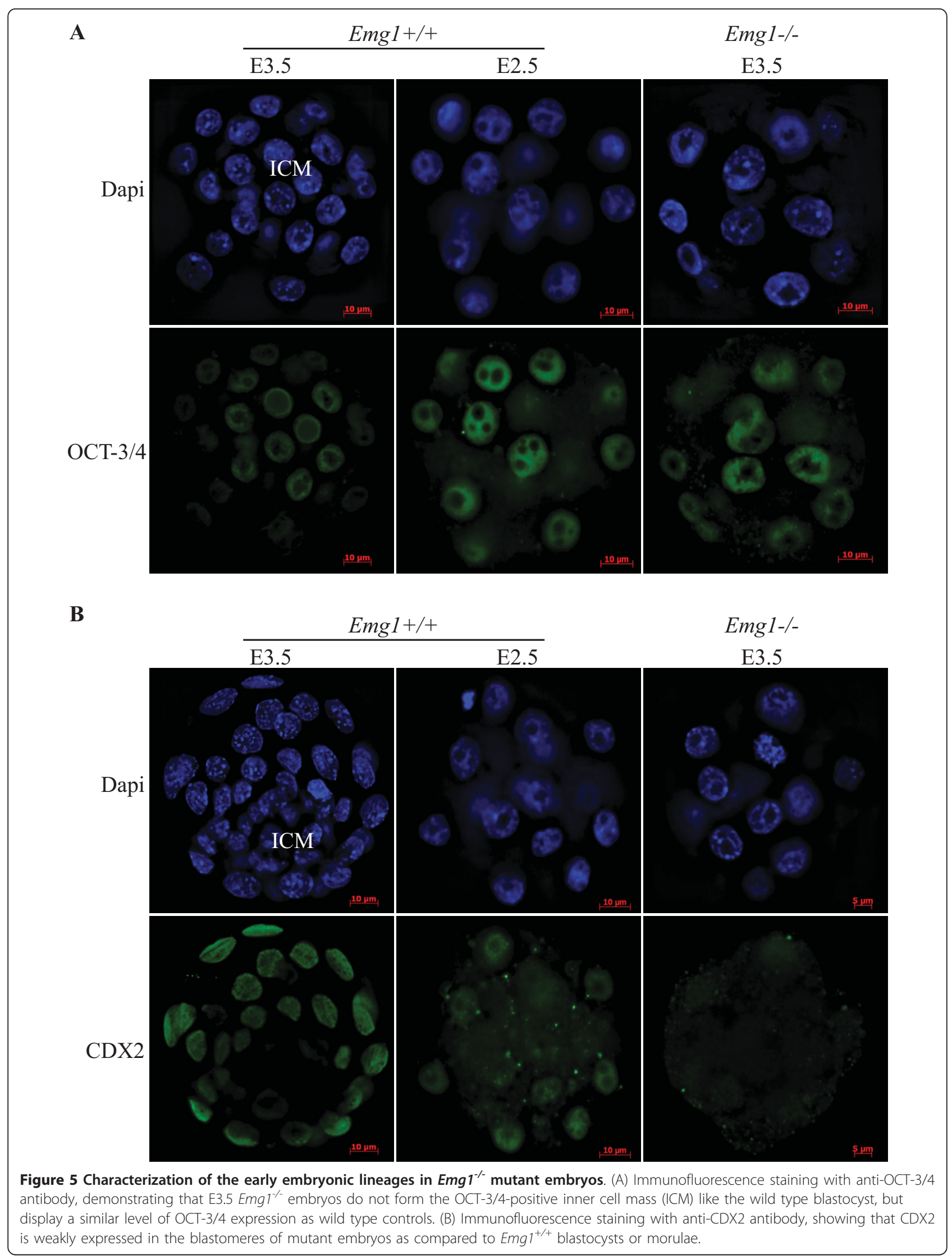


Some of these genetic mutations have been clearly demonstrated to cause severe defects in ribosomal biogenesis $[19,21,22]$. Thus, loss of EMG1 function in mice could also disrupt this biological pathway, leading to pre-implantation lethality.

To address this question, we first determined whether loss of EMG1 could affect nucleologenesis during preimplantation development. As demonstrated previously, "de novo" nucleologenesis which begins at the two-cell stage is critical for the resumption of rRNA transcription during early embryogenesis [25-27]. This process involves the morphological transformation of the nucleolus precursor body (NPB) to a mature, tripartite nucleolus as seen in the blastocysts $[27,28]$. To determine the effect of the Emg1 gene-deletion on nucleologenesis, we performed IF staining for the nucleolar makers B23/nucleophosmin and fibrillarin in E3.5 embryos harvested from $E m g 1^{+/}$intercrosses. As shown in Figure 6, in E3.5 Emg1 ${ }^{+/+}$or $E m g 1^{+/}$embryos, the nucleoli are smaller and more irregular than NPBs in E2.5 morula, indicating a striking maturation occurred at this developmental stage. In contrast, the nucleoli in E3.5 $\mathrm{Emgl}^{-/}$embryos still showed the large ring shape, closely resembling the NPBs observed in E2.5 wild-type morula. Therefore, these data strongly suggest that deletion of the Emg1 gene arrests nucleologenesis during early embryonic development.

To determine if Emg1/-embryos exhibit defective 40S ribosome biogenesis, similar to yeast depleted in yEMG1, we examined the level of mature 18S rRNA using reverse transcription (RT) followed by PCR. Although the levels of $18 \mathrm{~S}$ rRNA are significantly reduced in yeast depleted in yEMG1, no detectable decrease in $18 \mathrm{~S}$ rRNA were detected in $E m g 1^{-1-}$ morulae at E2.5 as compared to wild-type embryos at the same developmental stage (Figure 6B). Since E2.5 mouse morulae could contain residual maternal rRNAs, we used the same approach to analyze 18S rRNA in E3.5 $E m g 1^{-/-}$embryos as compared to wild-type embryos with the same developmental stage. Again, no difference was observed (Figure 6C). Given that the levels of $18 \mathrm{~S}$ rRNA in cells are very high, and small differences would not be detectable using this assay, we also looked for an increase in the precursors to the 18S rRNA, the pre-rRNA, but again no obvious difference between $\mathrm{Emg1}^{-/-}$and wild type or heterozygous embryos was detected (Figure 6C). The unchanged expression of $18 \mathrm{~S}$ rRNA and 47S rRNA in Emg1 $1^{-/}$embryos was also indicated by RT followed by real-time PCR analysis (data not shown). Although this data differs from that in yeast, it is still possible that there is a delay in ribosomal RNA processing or assembly that was not detected using these assays. More sensitive approaches such as metabolic labeling or pre-rRNA specific probes may be required to show a delay in rRNA processing, as was recently shown in the study of a protein required for the maturation of the $60 \mathrm{~S}$ ribosomal subunit in human cells [29]. However, due to the early pre-implantation lethality of the Emg1 null allele, we are unable to derive EMG1-deficient cells in which to perform these assays. Future experiments with a conditional knockout of EMG1 will greatly help to address the role of EMG1 in the regulation of ribosomal biogenesis during development.

\section{P53 deficiency does not rescue the pre-implantation arrest of $\mathrm{Emg}^{-/-}$mice}

Previous studies have found that mutations in many proteins involved in ribosome biogenesis lead to an upregulation of p53 [30-32], a key regulator of the cell cycle and apoptosis. The importance of p53 in the regulation of ribosome biogenesis has been addressed by studies showing that inhibition of p53 can suppress the effects of some defects in ribosome biogenesis. In mice, p53 inhibition was found to suppress the effects of mutation of Tcof (Treacher Collins syndrome-causing gene) [33] and Rps24 (Diamond-Blackfan anemia-causing gene) [34]. These findings suggest that the inhibition of p53 may suppress the detrimental effects of mutations in other disorders of ribosomal biogenesis, such as EMG1 deficiency. To test this, E3.5 embryos were collected from intercrosses of $E m g 1 / p 53$ double heterozygotes $\left(E m g 1^{+/-} / p 53^{+/-}\right)$or $E m g 1^{+/-} / p 53^{-/-}$. A total of $5 \mathrm{Emg1} \mathrm{T}^{-/} / \mathrm{p}^{-1-} \mathrm{E} 3.5$ embryos were identified, and all of them were found to be arrested at morula stage like the $\mathrm{Emg}^{-1-}$ null mutants (Additional file 2). In addition, none of E3.5 Emg1/ $/ \mathrm{p}^{-/} 3^{-/}$embryos developed to blastocysts during in vitro culture. Taken together, these data demonstrate that p53 inactivation fails to rescue the pre-implantation arrest of the Emg1 null allele.

In summary, we have demonstrated that EMG1 is essential for mouse pre-implantation. We showed that loss of EMG1 function specifically arrests early embryonic development at the morula stage, preventing blastocyst formation. This phenotype is consistent with our expression data showing that Emg1 is highly expressed during this critical developmental stage. However, due to the high expression of Emg1 in mouse oocytes (Figure 2N), which could be maternally transmitted into early developing embryos like other nucleolar components [35] (Figure 1D), we could not exclude the possibility that EMG1 is also required before the morula stage. Future experiments with a conditional knockout of EMG1 specifically in mouse oocytes will allow us to answer this question. Nevertheless, our study highlights a critical role of EMG1 in mouse early embryonic development. 


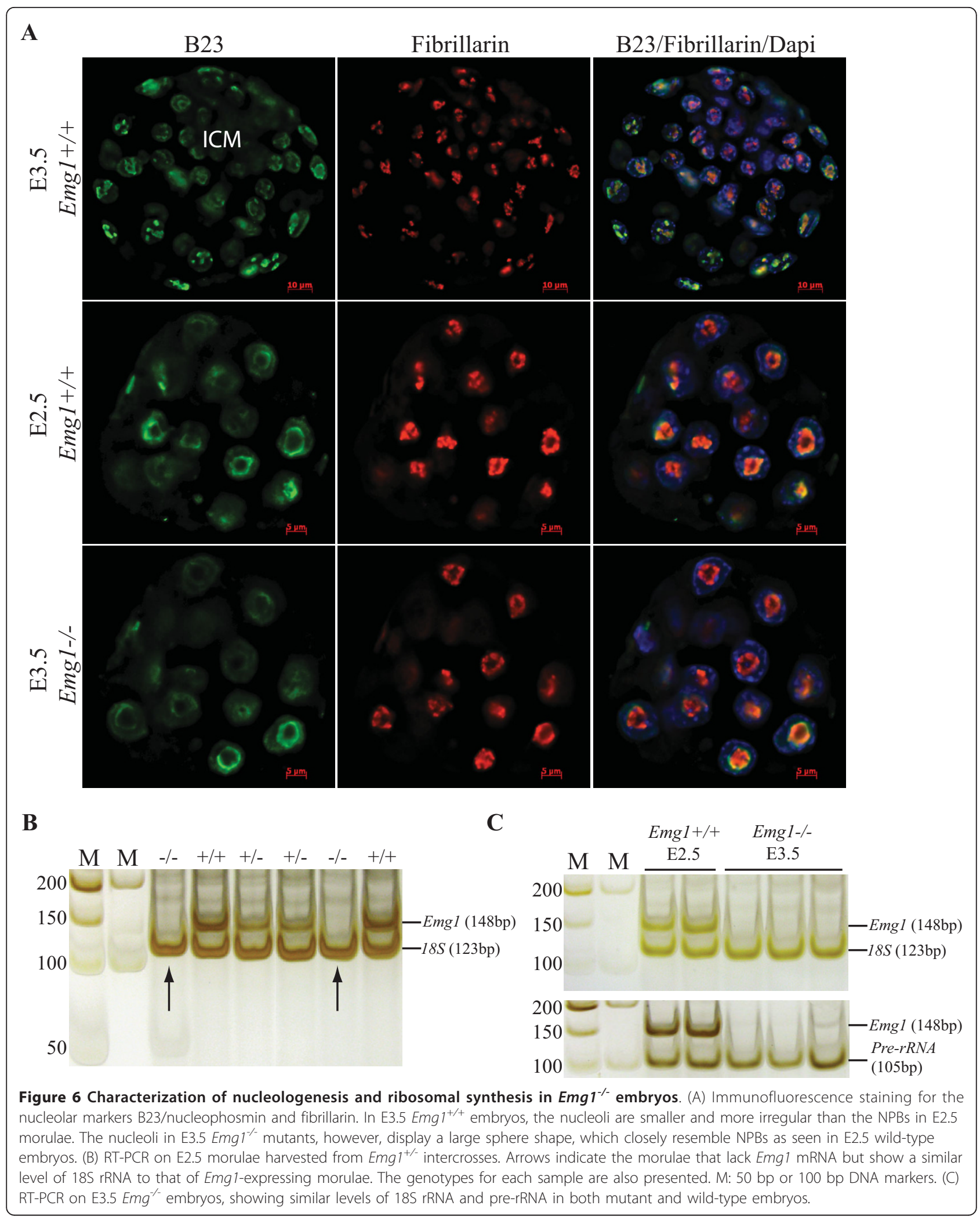


The importance of EMG1 in development has also been demonstrated by our recent finding that this gene is mutated in human BCS syndrome, a severe developmental disorder with prenatal and postnatal growth retardation, profound psychomotor deficit, and death in early childhood [36]. Because of this mutation, the EMG1 protein was found to be significantly reduced in fibroblasts of BCS patients [12]. The residual protein that is detected is likely necessary to allow survival, as mice with a complete deficiency of EMG1 exhibit preimplantation lethality. Therefore, the involvement of EMG1 in development could be dose-dependant. The hypomorphic mutation of EMG1 in BCS could specifically affect late embryonic development or certain cell lineages to cause BCS-associated phenotypes. In line with this, in this study, we found that Emg1 is predominately expressed in distinct cell types at late embryonic developmental stages or in adult (Figure 2). The unique expression of Emg1 in the granular neurons of cerebellum or in hippocampus could underly an important role for EMG1 in the control of psychomotor development, whose dysfunction is characteristic of BCS. Future experiments with mouse alleles to allow knockin of the BCS mutation, or a conditional allele, will allow us to address the pathological role(s) of EMG1 in vivo.

\section{Conclusions}

We have provided direct genetic evidence that EMG1 is essential for mouse pre-implantation. Given the requirement of yEMG1 in the biogenesis of the ribosomal $40 \mathrm{~S}$ subunit, our study also highlights the critical role of ribosomal biogenesis in early development. The absolute requirement for EMG1 in mouse development is consistent with its essential role in yeast. Further, our findings also lend support to the previous study that showed Bowen-Conradi syndrome results from a partial EMG1 deficiency. A complete deficiency would not be expected to be compatible with a live birth.

\section{Methods}

\section{Construction of the Emg1 gene-targeting vector}

The Emg1 gene-targeting vector was made based on a PCR-based cloning strategy as described previously [37]. Briefly, the mouse Emg1 genomic fragments required for the 5' and 3' arms of homology were PCR-amplified from the genomic DNA of R1 ES cells (on 129S1 background) with a high-fidelity polymerase (Clontech). After validation by DNA sequencing, the PCR products were cloned into two individual vectors that contain the SA-IRESßgeo cassette, and a $p G K D T A$ fragment (the negative selection cassette), respectively. Subsequently, using the restriction enzymes and the cloning strategy as described [37], the DNA fragments were isolated, and assembled together to generate the gene-targeting vector.

\section{Generation of Emg1 deficient mice}

The Emg1 gene-targeting construct was linearized and electroporated into R1 ES cells, and then selected with G418 $(250 \mu \mathrm{g} / \mathrm{ml})$. The G418 resistant ES clones were screened by Southern blot analysis for the correctly targeted allele using EcoR1 (for the 5' external probe) and $B a m H 1$ (for the 3' external probe) digestion. Two independently targeted ES cell clones were used to generate chimeric mice that subsequently transmitted the genetic alternation through the germ line. The phenotypes of $E m g 1^{-1-}$ mutants derived from both targeted ES cell lines were indistinguishable. Mice were maintained on either 129S1 or on a mixed 129S1 and CD1/ICR background, in which $E m g 1^{-/}$developed the same phenotype. All mouse experiments were performed in accordance with procedures approved by the University of Manitoba Animal Care and Use Committee.

\section{Genotyping}

PCR and Southern blot analysis were applied for genotyping the Emg1 heterozygous mice. PCR was performed on ear-punched DNA. Primers to amplify the targeted allele were the sense primer (P1), located in intron 2 (5'-GTTCCTCAGCATATACGTGCT-3') and antisense primer (P2) specific for the SA-IRESBgeopA cassette (5'-GGGACAGGATAAGTATGACATCA-3'). To detect the wild-type Emg1 allele, P1 primer and an antisense primer (P3) locating in exon 2 (5'-TGTAAACCTGTAGCAAGCCAGCT-3') were used for PCR. Southern blot analysis was undertaken using standard protocols.

To genotype pre-implantation mouse embryos, a nested PCR method was applied. DNA was prepared by incubating E2.5-E3.5 embryos with $10 \mu \mathrm{l}$ of Proteinase $\mathrm{K}$ buffer $\left(10 \mathrm{mM}\right.$ Tris $\mathrm{pH} 8.3,50 \mathrm{mM} \mathrm{KCl}, 2 \mathrm{mM} \mathrm{MgCl}{ }_{2}$, $0.01 \%$ gelatin, $0.45 \%$ Nonidet $\mathrm{P} 40,0.45 \%$ Tween 20 and $500 \mu \mathrm{g} / \mathrm{ml}$ proteinase $\mathrm{K}$ ) for $1 \mathrm{~h}$ at $55^{\circ} \mathrm{C}$ followed by incubation at $95^{\circ} \mathrm{C}$ for $10 \mathrm{~min} .5 \mu \mathrm{l}$ of DNA sample was then directly used for PCR using P1 and P2 (for the Emg1 targeted allele) and P1 and P3 (for the wild-type allele). $2 \mu \mathrm{l}$ of products from the first round PCR were further PCR-amplified with the internal primers, generating $264 \mathrm{bp}$ (wild-type allele) and $353 \mathrm{bp}$ (targeted allele) products, respectively.

A similar approach was also applied to genotype the $p 53$ null allele in Emg1/p53 double mutant pre-implantation embryos. The first round PCR was done using the primers as described previously [38]. In the second round PCR, the following internal primers were utilized: 5'-TACCTCACTACAGGTGACCTG-3' (sense) and 5'-TCTTAGAGACAGTTGACTCCAG-3' (antisense) (for detecting the p53 wild-type allele), and 5'- TACCTCACTACAGGTGACCTG-3' (sense) and 5'-GTGATATTGCTGAAGAGCTTGG-3' (antisense) (for detecting the p53 null allele). 
Early embryo isolation and in vitro culture $\mathrm{Emg1}^{+/-}$or $E m g 1^{+/-} / \mathrm{p} 3^{+/-}$mice were intercrossed, and the females were examined for the presence of a vaginal plug which was set as embryonic day (0.5). Embryos at different stages of development (E2.5 through E3.5) were collected by either dissecting ampullae or flushing oviducts with M2 medium (Millipore). For in vitro culturing, E3.5 embryos were placed in $\mathrm{KSOM}-1 / 2 \mathrm{AA}$ medium (Millipore), and incubated at $37^{\circ} \mathrm{C}$ for $24 \mathrm{~h}$.

\section{Immuno-staining of pre-implantation embryos}

Immuno-staining of pre-implantation embryos was performed based on the protocols provided by Dr. Janet Rossant http://www.sickkids.ca/research/rossant/custom/ protocols.asp. The following antibodies were used: monoclonal anti-CDX2 (1:200, CDX2-88, BioGenex, CA, USA), monoclonal mouse anti-OCT3/4 (1:50, C10; Santa Cruz Biotechnology), rabbit anti-NANOG (1:200, Cosmo Bio), Rat anti-E-cadherin (1:100, Sigma), monoclonal mouse anti-B23 (1:50, Invitrogen) and rabbit anti-fibrillarin (1:100, Abcam). Secondary antibodies included Texas Red or Alexa488-conjugated goat anti-mouse, goat antirat and goat anti-rabbit (Molecular Probes). To visualize nuclei, embryos were stained with DAPI $(0.5 \mu \mathrm{g} / \mathrm{ml})$ for 3 min at room temperature. Immuno-stained embryos were mounted onto microscopic slides with ProLong Gold (Invitrogen) and covered with glass cover slips. Images were collected using a Zeiss Axioplan 2 microscope to generate Z-stacks which were deconvolved using iterative algorithms program in Axio Vision 4.6.

For the BrdU labeling assay, E2.5-E3.5 embryos were incubated with KSOM-1/2AA medium containing 10 $\mu \mathrm{M}$ BrdU (Sigma) for $3 \mathrm{~h}$, and were then fixed in $4 \%$ paraformaldehyde (PFA) for $10 \mathrm{~min}$, permeabilized in $0.25 \%$ Triton X-100 for $10 \mathrm{~min}$, treated with $2 \mathrm{~N} \mathrm{HCl}$ for $10 \mathrm{~min}$, and detected with anti-BrdU antibody (Sigma).

\section{TUNEL staining}

E2.5-E3.5 mouse embryos were fixed in 4\% PFA in PBS for $1 \mathrm{~h}$ at room temperature, and permeabilized for $1 \mathrm{~h}$ in PBS- $0.5 \%$ Triton X-100. The embryos were then washed three times in PBS-0.1\% Trion X-100 and incubated at $37^{\circ} \mathrm{C}$ for $1 \mathrm{~h}$ in a staining solution containing biotin-dUTP, terminal deoxynucleotide transferase (TdT), and detected using an $\mathrm{ABC}$ staining kit (Vector).

\section{Whole mount $x$-gal staining}

Pre-implantation embryos were fixed for 2 min with $1 \%$ PFA, $0.2 \%$ glutaraldehyde and $0.02 \%$ NP40 in PBS. After fixation, embryos were washed three times with PBS containing $0.02 \% \mathrm{NP} 40$, and stained at $37^{\circ} \mathrm{C}$ overnight with a staining solution $\left(4 \mathrm{mM} \mathrm{K}_{4} \mathrm{Fe}(\mathrm{CN})_{6}, 4 \mathrm{mM} \mathrm{K}_{3} \mathrm{Fe}(\mathrm{CN})_{6}, 2\right.$ $\mathrm{mM} \mathrm{MgCl}$, and $0.2 \% \mathrm{X}$-gal in PBS). For E8.5-E9.5 embryos, embryos were fixed for 30 min with $4 \%$ PFA.
After extensive washing with PBS containing 0.02\% NP40 (three times, $20 \mathrm{~min} /$ each time), embryos were stained as described above.

\section{RNA in situ hybridization}

RNA in situ analysis of whole mount mouse embryos and frozen sections of mouse tissues were performed according to established protocols [39] with antisense and sense digoxigenin-labeled riboprobes which were in vitro transcribed from the full-length mouse Emg1 coding sequence. Mouse embryos were collected from pregnant outbred ICR female mice at E9.5-E15.5 days of gestation, and the adult tissues were harvested from two-month old ICR mice. All the samples were fixed in DEPC-treated $4 \%$ PFA at $4{ }^{\circ} \mathrm{C}$ overnight.

RNA in situ hybridization on early mouse embryos (E2.5-E3.5) was performed essentially based on a described protocol [40]. To preserve the pre-implantation embryos, the whole procedure was carried out in a transwell-insert (Corning).

\section{Northern Blot Analysis}

Total RNA from flash-frozen mouse tissues was extracted using TRIzol (Life Technologies, Inc.). $20 \mu \mathrm{g}$ of total RNA was separated on a $1 \%$ agarose-formaldehyde gel and transferred to Hybond nylon membrane (Amersham). Hybridization was carried out in PerfectHyb (Sigma) with $1.5 \times 10^{6} \mathrm{cpm} / \mathrm{ml}$ probe which covers the whole coding sequence of Emg1.

\section{RT-PCR analysis of pre-implantation embryos}

Each blastocyst or morula was lysed with $5 \mu \mathrm{l}$ ice-cold Cell Lysis II Buffer (Ambion) for $10 \mathrm{~min}$ at $75^{\circ} \mathrm{C} .2 \mu \mathrm{l}$ of lysate was used for PCR based genotyping, the rest was digested with DNase1 (0.08 unit/ $\mu$ l, Ambion) at $37^{\circ} \mathrm{C}$ for $15 \mathrm{~min}$. After inactivation at $75^{\circ} \mathrm{C}$ for $5 \mathrm{~min}, 2 \mu \mathrm{l}$ of DNase1-treated embryonic lysate was used in an RT reaction in a $10 \mu \mathrm{l}$ volume using the OneStep RT-PCR kit (Qiagen) according to the manufacturer's instructions. The final concentration of specific primers (see the reverse primers described below) was $0.6 \mu \mathrm{M}$ each. $2 \mu \mathrm{l}$ R mixture were then used for PCR reactions with the Multiplex PCR kit (Qiagen) and the primers described below. The PCR cycles contain an initial denaturation step of $95^{\circ} \mathrm{C}$ for $15 \mathrm{~min}$ and 40 cycles of $94^{\circ} \mathrm{C}$ for $30 \mathrm{~s}, 60^{\circ} \mathrm{C}$ for $90 \mathrm{~s}$, and $72^{\circ} \mathrm{C}$ for $60 \mathrm{~s}$, and a final 10 min extension step at $72^{\circ} \mathrm{C}$. The PCR products were separated on a $12 \%$ polyacrylamide gel in $1 \times$ Trisborate-EDTA buffer. The bands on the gel were visualized by the silver staining method as described [41].

The following primers were used for the above RT-PCR analysis: Mouse Emg1: forward (5'-TGAAGTGAACCCCCAGACTC-3') and reverse (5'-GAAGTGGTCGGACACTGGAT-3'). The amplified DNA band is $148 \mathrm{bp}$. Mouse 
pre-rRNA: forward (5'-CTCCTGTCTGTGGTGTCCAA$3^{\prime}$ ) and reverse (5'-TGATACGGGCAGACACAGAA-3') in the 5' external transcribed spacer (5'-ETS) region of mouse $47 \mathrm{~S}$ pre-rRNA [42]. The size of the PCR product is $105 \mathrm{bp}$. Mouse $18 \mathrm{~S}$ rRNA: forward (5'-GCAATTATTCCCCATGAACG-3') and reverse (5'-GGCCTC ACTAAACCATCCAA-3'), which gives rise to a DNA band with $123 \mathrm{bp}$.

\section{Additional material}

\section{Additional file 1: Expression of NANOG in $\mathrm{Emg}^{-/-}$mutant embryos}

E3.5 embryos from Emg ${ }^{+/}$intercross were co-immunostained with antiNANOG (red) and anti- $\beta$-catenin (green) antibodies. In E3.5 Emg $1^{+/+}$ blastocysts, nuclear-localized NANOG is mainly found in the ICM. NANOG is also detected in the blastomeres of E2.5 Emg ${ }^{+/+}$morulae. At E3.5, Emg $1^{-1}$ embryos arrest at the morula stage, in which the blastomeres express similar levels of NANOG as that in E2.5 Emg1 ${ }^{+/+}$morulae.

\section{Additional file 2: p53 inactivation fails to rescue the pre-} implantation arrest of the Emg1 null allele. E3.5 embryos were

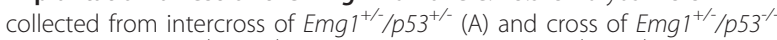

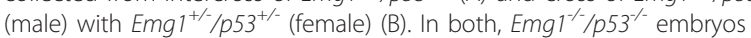
show the same morula arrest as $\mathrm{Emg}^{-/} /{\mathrm{p} 53^{+/}}^{+/}$or Emg $\mathrm{Embryos}^{-/}$. Scale bar, $100 \mu \mathrm{m}$

\section{Abbreviations}

EMG1: Essential for mitotic growth 1; BCS: Bowen-Conradi syndrome; rRNAs: ribosomal RNAs; SAM: S-adenosyl methionine; ICM: inner cell mass; PES-1: pescadillo-1; Rbm19: RNA-binding motif protein 19; Rps19: ribosomal protein S19; IF: immunofluorescence; PFA: paraformaldehyde; TdT: Terminal deoxynucleotide transferase; RT: reverse transcription.

\section{Acknowledgements}

We thank Dr. Janet Rossant at the University of Toronto and Dr. Hiroshi Hamada at Osaka University for providing reagents and advice on the characterization of mouse pre-implantation embryos. We also thank Mr. Biswajit Chowdhury for assistance with the mouse breeding and colony maintenance. This study was supported by funding from Genome Canada (grant number: 308-162340200-2000 to H.D.) and the Canadian Institute of Health Research (MOP 62786 to B.T.R.). S.S. is supported by a studentship from NSERC (Natural Sciences and Engineering Research Council of Canada), and H.D. is a recipient of Canada Research Chair.

\section{Author details}

'Department of Biochemistry and Medical Genetics, University of Manitoba, 745 Bannatyne Avenue, Winnipeg R3E 0J9, Canada. ${ }^{2}$ Department of Pediatrics \& Child Health, University of Manitoba, 840 Sherbrook Street, Winnipeg R3A 1S1, Canada. ${ }^{3}$ Center for the Investigation of Genetic Disease, Manitoba Institute of Child Health, 715 McDermot Avenue, Winnipeg R3E 3P4, Canada.

\section{Authors' contributions}

XW, BT and HD conceived and designed the experiments. XW and SS performed in situ and Northern hybridization. XW, SS and HD generated the gene-targeting vector and produced the knockout mice. XW and NP performed mouse breeding and genotyping and XW did all the analysis of the pre-implantation mouse embryos. BT and HD wrote the manuscript with subsequent contributions from all authors. All authors read and approved the final manuscript.

Received: 18 March 2010 Accepted: 21 September 2010 Published: 21 September 2010

\section{References}

1. Warner JR: The economics of ribosome biosynthesis in yeast. Trends Biochem Sci 1999, 24:437-440

2. Moss T, Langlois F, Gagnon-Kugler T, Stefanovsky V: A housekeeper with power of attorney: the rRNA genes in ribosome biogenesis. Cell Mol Life Sci 2007, 64:29-49.

3. Connolly K, Culver G: Deconstructing ribosome construction. Trends Biochem Sci 2009, 34:256-263.

4. Hakuno F, Hughes DA, Yamamoto M: The Schizosaccharomyces pombe mra1 gene, which is required for cell growth and mating, can suppress the mating inefficiency caused by a deficit in the Ras 1 activity. Genes Cells 1996, 1:303-315.

5. Liu PC, Thiele DJ: Novel stress-responsive genes EMG1 and NOP14 encode conserved, interacting proteins required for $40 \mathrm{~S}$ ribosome biogenesis. Mol Biol Cell 2001, 12:3644-3657.

6. Eschrich D, Buchhaupt M, Kotter P, Entian KD: Nep1p (Emg1p), a novel protein conserved in eukaryotes and archaea, is involved in ribosome biogenesis. Curr Genet 2002, 40:326-338.

7. Lowe TM, Eddy SR: A computational screen for methylation guide snoRNAs in yeast. Science 1999, 283:1168-1171.

8. Bernstein KA, Gallagher JE, Mitchell BM, Granneman S, Baserga SJ: The small-subunit processome is a ribosome assembly intermediate. Eukaryot Cell 2004, 3:1619-1626.

9. Buchhaupt M, Meyer B, Kotter P, Entian KD: Genetic evidence for 18S rRNA binding and an Rps19p assembly function of yeast nucleolar protein Nep1p. Mol Genet Genomics 2006, 276:273-284.

10. Wurm JP, Meyer B, Bahr U, Held M, Frolow O, Kotter P, Engels JW, Heckel A Karas M, Entian KD, Wohnert J: The ribosome assembly factor Nep1 responsible for Bowen-Conradi syndrome is a pseudouridine-N1-specific methyltransferase. Nucleic Acids Res 2010.

11. Taylor AB, Meyer B, Leal BZ, Kotter P, Schirf V, Demeler B, Hart PJ, Entian KD Wohnert J: The crystal structure of Nep1 reveals an extended SPOUTclass methyltransferase fold and a pre-organized SAM-binding site. Nucleic Acids Res 2008, 36:1542-1554.

12. Armistead J, Khatkar S, Meyer B, Mark BL, Patel N, Coghlan G, Lamont RE, Liu S, Wiechert J, Cattini PA, Koetter P, Wrogemann K, Greenberg CR, Entian KD, Zelinski T, Triggs-Raine B: Mutation of a gene essential for ribosome biogenesis, EMG1, causes Bowen-Conradi syndrome. Am J Hum Genet 2009, 84:728-739.

13. Ding $H$, Schertzer $M$, Wu $X$, Gertsenstein $M$, Selig S, Kammori M, Pourvali $R$, Poon S, Vulto I, Chavez E, Tam PP, Nagy A, Lansdorp PM: Regulation of murine telomere length by Rtel: an essential gene encoding a helicaselike protein. Cell 2004, 117:873-886.

14. Palmieri SL, Peter W, Hess H, Scholer HR: Oct-4 transcription factor is differentially expressed in the mouse embryo during establishment of the first two extraembryonic cell lineages involved in implantation. Dev Biol 1994, 166:259-267.

15. Chambers I, Colby D, Robertson M, Nichols J, Lee S, Tweedie S, Smith A: Functional expression cloning of Nanog, a pluripotency sustaining factor in embryonic stem cells. Cell 2003, 113:643-655.

16. Mitsui K, Tokuzawa Y, Itoh H, Segawa K, Murakami M, Takahashi K, Maruyama M, Maeda M, Yamanaka S: The homeoprotein Nanog is required for maintenance of pluripotency in mouse epiblast and ES cells. Cell 2003, 113:631-642.

17. Beck F, Erler T, Russell A, James R: Expression of Cdx-2 in the mouse embryo and placenta: possible role in patterning of the extra-embryonic membranes. Dev Dyn 1995, 204:219-227.

18. Zhang J, Tomasini AJ, Mayer AN: RBM19 is essential for preimplantation development in the mouse. BMC Dev Biol 2008, 8:115.

19. Lerch-Gaggl A, Haque J, Li J, Ning G, Traktman P, Duncan SA: Pescadillo is essential for nucleolar assembly, ribosome biogenesis, and mammalian cell proliferation. J Biol Chem 2002, 277:45347-45355.

20. Newton K, Petfalski E, Tollervey D, Caceres JF: Fibrillarin is essential for early development and required for accumulation of an intron-encoded small nucleolar RNA in the mouse. Mol Cell Biol 2003, 23:8519-8527.

21. Chen H, Li Z, Haruna K, Li Z, Li Z, Semba K, Araki M, Yamamura K, Araki K: Early pre-implantation lethality in mice carrying truncated mutation in the RNA polymerase 1-2 gene. Biochem Biophys Res Commun 2008, 365:636-642. 
22. Adachi K, Soeta-Saneyoshi C, Sagara H, Iwakura Y: Crucial role of Bysl in mammalian preimplantation development as an integral factor for $40 \mathrm{~S}$ ribosome biogenesis. Mol Cell Biol 2007, 27:2202-2214.

23. Romanova LG, Anger M, Zatsepina OV, Schultz RM: Implication of nucleolar protein SURF6 in ribosome biogenesis and preimplantation mouse development. Biol Reprod 2006, 75:690-696.

24. Matsson H, Davey EJ, Draptchinskaia N, Hamaguchi I, Ooka A, Leveen P, Forsberg E, Karisson S, Dahl N: Targeted disruption of the ribosomal protein S19 gene is lethal prior to implantation. Mol Cell Biol 2004, 24:4032-4037

25. Geuskens $\mathrm{M}$, Alexandre $\mathrm{H}$ : Ultrastructural and autoradiographic studies of nucleolar development and rDNA transcription in preimplantation mouse embryos. Cell Differ 1984, 14:125-134.

26. Flechon JE, Kopecny $V$ : The nature of the 'nucleolus precursor body' in early preimplantation embryos: a review of fine-structure cytochemical, immunocytochemical and autoradiographic data related to nucleolar function. Zygote 1998, 6:183-191.

27. Zatsepina O, Baly C, Chebrout M, Debey P: The step-wise assembly of a functional nucleolus in preimplantation mouse embryos involves the cajal (coiled) body. Dev Biol 2003, 253:66-83.

28. Flechon JE, Kopecny $\mathrm{V}$ : The nature of the 'nucleolus precursor body' in early preimplantation embryos: a review of fine-structure cytochemical, immunocytochemical and autoradiographic data related to nucleolar function. Zygote 1998, 6:183-191.

29. Castle CD, Cassimere EK, Lee J, Denicourt C: Las1L Is a Nucleolar Protein Required for Cell Proliferation and Ribosome Biogenesis. Mol Cell Biol 2010, 30:4404-4414.

30. Panic L, Montagne J, Cokaric M, Volarevic S: S6-haploinsufficiency activates the p53 tumor suppressor. Cell Cycle 2007, 6:20-24.

31. Pestov DG, Strezoska Z, Lau LF: Evidence of p53-dependent cross-talk between ribosome biogenesis and the cell cycle: effects of nucleolar protein Bop1 on G(1)/S transition. Mol Cell Biol 2001, 21:4246-4255.

32. Rubbi CP, Milner J: Disruption of the nucleolus mediates stabilization of p53 in response to DNA damage and other stresses. EMBO J 2003, 22:6068-6077.

33. Jones NC, Lynn ML, Gaudenz K, Sakai D, Aoto K, Rey JP, Glynn EF, Ellington L, Du C, Dixon J, Dixon MJ, Trainor PA: Prevention of the neurocristopathy Treacher Collins syndrome through inhibition of p53 function. Nat Med 2008, 14:125-133.

34. Barkic M, Crnomarkovic S, Grabusic K, Bogetic I, Panic L, Tamarut S, Cokaric M, Jeric I, Vidak S, Volarevic S: The p53 tumor suppressor causes congenital malformations in Rpl24-deficient mice and promotes their survival. Mol Cell Biol 2009, 29:2489-2504.

35. Ogushi S, Palmieri C, Fulka H, Saitou M, Miyano T, Fulka J Jr: The maternal nucleolus is essential for early embryonic development in mammals. Science 2008, 319:613-616.

36. Lowry RB, Innes AM, Bernier FP, McLeod DR, Greenberg CR, Chudley AE, Chodirker B, Marles SL, Crumley MJ, Loredo-Osti JC, Morgan K, Fujiwara TM: Bowen-Conradi syndrome: a clinical and genetic study. Am J Med Genet 2003, 120A:423-428

37. Wu $\mathrm{X}$, Ding $\mathrm{H}$ : Generation of conditional knockout alleles for PDGF-C. Genesis 2007, 45:653-657.

38. Jacks T, Remington L, Williams BO, Schmitt EM, Halachmi S, Bronson RT, Weinberg RA: Tumor spectrum analysis in p53-mutant mice. Curr Biol 1994, 4:1-7.

39. Ding H, Wu X, Kim I, Tam PP, Koh GY, Nagy A: The mouse Pdgfc gene: dynamic expression in embryonic tissues during organogenesis. Mech Dev 2000, 96:209-213.

40. Piette D, Hendrickx M, Willems E, Kemp CR, Leyns L: An optimized procedure for whole-mount in situ hybridization on mouse embryos and embryoid bodies. Nat Protoc 2008, 3:1194-1201.

41. Bassam BJ, Gresshoff PM: Silver staining DNA in polyacrylamide gels. Nat Protoc 2007, 2:2649-2654.

42. Strezoska Z, Pestov DG, Lau LF: Functional inactivation of the mouse nucleolar protein Bop1 inhibits multiple steps in pre-rRNA processing and blocks cell cycle progression. J Biol Chem 2002, 277:29617-29625.

doi:10.1186/1471-213X-10-99

Cite this article as: Wu et al:: EMG1 is essential for mouse preimplantation embryo development. BMC Developmental Biology 2010 10:99.

\section{Submit your next manuscript to BioMed Central and take full advantage of:}

- Convenient online submission

- Thorough peer review

- No space constraints or color figure charges

- Immediate publication on acceptance

- Inclusion in PubMed, CAS, Scopus and Google Scholar

- Research which is freely available for redistribution 